\title{
ПРОГНОЗИРОВАНИЕ ОСНОВНЫХ ПАРАМЕТРОВ СОЦИАЛЬНО-ЭКОНОМИЧЕСКОГО РАЗВИТИЯ РЕСПУБЛИКИ БЕЛАРУСЬ НА ОСНОВЕ ДИНАМИЧЕСКОЙ МЕЖОТРАСЛЕВОЙ МОДЕЛИ
}

\author{
М.К. Кравцов, А.А. Гладкая, Т.А. Дехтярь
}

Приведена расширенная версия динамической балансово-эконометрической межотраслевой модели прогнозирования основных макропоказателей белорусской экономики, включая показатели оплаты труда работников, валовой прибыли и валового смешанного дохода, других налогов на производство за вычетом субсидий. Представлены переоцененные, а некоторые из них и усовершенствованные эконометрические модели прогнозирования коэффициентов прямых затрат, валовых выпусков в разрезе агрегатов и основных элементов конечного спроса по республике. Проведены прогнозные расчеты на основе статистической информации Республики Беларусь за 2017-2018 гг., результаты которых свидетельствуют о приемлемой точности прогноза и возможности использования предложенных моделей при разработке прогнозов и программ социально-экономического развития страны.

Ключевые слова: межотраслевой баланс, система таблиц «Затраты - Выпуск», динамическая межотраслевая модель, балансово-эконометрическая модель.

JEL-классификация: D57, O11, E17.

DOI: $10.46782 / 1818-4510-2020-2-4-24$

Материал поступил 3.03.2020 2.

Одним из основных направлений использования науки в практике является разработка прогнозов (Шимов, Александрович, Богданович, Ткачев, 2001). В настоящее время можно отметить непрерывно растущую потребность в них, связанную с постоянным усложнением всех сторон жизни общества, динамическим развитием социально-экономических процессов, тесным взаимодействием экономики, науки и техники, отражением различий в условиях производства и жизнедеятельности по странам и регионам.

Динамические модели в экономике описывают изменение моделируемой системы во времени. Обычно время в таких моделях представляется явно - либо как непрерывная величина, либо дискретно, конечным набором или бесконечной последовательностью дискретных значений. Математическое описание динамических моделей производится с помощью систем дифференциальных уравнений (в моделях с непрерывным временем), разностных уравнений (в моделях с дискретным временем), а также систем обыкновенных алгебраических уравнений.

Первые работы по динамическим моделям экономики появились в конце 20-х годов ХХ века (Ф.П. Рамсей; Г.А. Фельдман). Наиболее глубокое изучение экономической динамики началось в 50-е годы XX века. Известный математик Дж. фон Нейман предложил динамическую многосекторную модель расширяющейся экономики, в которой все выпуски одного периода становятся затратами следующего периода, а первичные факторы в ней не используются ${ }^{1}$. Эта модель положила начало магистральной теории и в дальнейшем ока-

${ }^{1}$ von Neumann J. 1945. A model of general equilibrium. Review of Economic Studies. Vol. 13. No 1. PP. 1-9.

\footnotetext{
* Кравцов Михаил Константинович (kravtsov@economic.mailgov.by), доктор физико-математических наук, профессор, Научно-исследовательский экономический институт Министерства экономики Республики Беларусь (г. Минск, Беларусь);

Гладкая Александра Анатольевна (gladkayaalexandra@gmail.com), Научно-исследовательский экономический институт Министерства экономики Республики Беларусь (г. Минск, Беларусь);

Дехтярь Татьяна Александровна (tatiana.dehtyar.niei@gmail.com), Научно-исследовательский экономический институт Министерства экономики Республики Беларусь (г. Минск, Беларусь).
} 
зала существенное влияние на развитие современной математической экономики.

Неоценимый вклад в разработку и исследование экономической динамики внесли такие ученые как Д.Р. Хикс, Р.М. Солоу, К. Эрроу, Ж. Дебре, П.Э. Самуэльсон, В.В. Леонтьев, Л.В. Канторович, Г.С. Беккер, впоследствии определившие магистральные пути развития.

Проникновение математики в область экономики привело к возникновению новых направлений как в экономике, так и в самой математике. Проблема моделирования и прогнозирования экономики, ставшая в последнее время особенно актуальной, по праву является одной из ключевых в современном мире.

\section{обице подходь к моделированию экономики}

В научной литературе выделяют три основных подхода к моделированию экономики. Первый, основанный на использовании эконометрических методов и производственных функций, широко применяется во многих странах (Харемза, Харин, Макарова, Малюгин, Майковская, Гурин, Вымятнина, Раскина, 2007; Господарик, Ковалев, 2015; Айвазян, Березняцкий, Бродский, 2019). В Республике Беларусь он нашел применение в прогнозировании как отдельных макроэкономических показателей (Картун, 2019. С. 202-209), так и групп взаимосвязанных показателей (Кравцов, Бурдыко, Гаспадарец, Шинкевич, Картун, 2008. С. 21-43; Кравцов, Борейко, Никитина, 2013. С. 220-235; Борейко, Селицкая, Никонович, 2018. С. 248-259).

Результаты прикладного эконометрического анализа и моделирования процессов в белорусской экономике в условиях структурной неоднородности моделей описываются в монографии В.И Малюгина (2014).

Другой подход базируется на использовании вычислимых моделей общего равновесия - Computable General Equilibrium (CGE) моделей. В 1874 г. швейцарский экономист Л. Вальрас ${ }^{2}$ впервые поставил проблему о взаимодействии производителей и потребителей в рыночной экономике, суть

2 Вальрас Л. 2000. Элементы чистой политической экономики. Москва: Изограф. 448 с. которой состоит в следующем: так как каждый производитель и потребитель определяют свою экономическую деятельность в зависимости от цен на рынке товаров и услуг и рынке факторов производства (ресурсов), то существует ли такая система рыночных цен, при которой производители и потребители, действуя согласно своим экономическим интересам, действовали бы вместе с тем в совокупности согласованно, т. е. чтобы совокупное производство каждого продукта и совокупный спрос на него совпадали? Позднее, уже в середине XX в. эта проблема была решена ${ }^{3}$, а именно, было доказано, что такие рыночные цены существуют. Эти цены и были названы равновесными, а само состояние экономики при таких ценах назвали экономическим равновесием.

За последние 60 лет сформировалось и получило широкое распространение в мире новое направление, связанное с моделированием экономических процессов путем создания вычислимых моделей общего равновесия (Corong, Hertel, McDougall, Tsigas, Mensbrugghe, 2017; Макаров, Бахтизин, Бакларян, Акопов, Ровенская, Стрелковский, 2019).

Третий подход основан на использовании таблиц «Затраты - Выпуск» (межотраслевого баланса), который возник как результат экономической теории, с одной стороны, и потребностей практики управления экономикой - с другой. Большой вклад в разработку межотраслевого подхода внес В. Леонтьев ${ }^{4}$ - американский экономист, лауреат Нобелевской премии 1973 г. по экономике «За развитие метода экономического анализа «Затраты - Выпуск», используемого в различных формах более чем в 50 промышленных странах для планирования и прогнозирования». Он создал направление статистического анализа (input-output analysis), разработав методологию составления таблиц «Затраты - Выпуск», и на практике доказал безусловную ценность этого анализа для государственного регулирова-

\footnotetext{
${ }^{3}$ Arrow K.J., Debreu G. 1954. Existence of an equilibrium for a competitive economy. Econometrica. Vol. 22. No 3. PP. 265-290.

4 Леонтьев В. 1958. Исследование структуры американской экономики. Москва: Госстатиздат. 640 с.; Леонтьев В. 1997. Межотраслевая экономика. Москва: Экономика. 423 с.
} 
ния экономики и прогнозирования ее развития. Межотраслевой подход по-прежнему остается доминирующим, поскольку он дает возможность описать экономику страны в целом, учесть объективное единство и взаимосвязь всех элементов и аспектов воспроизводственного процесса, провести на основе таблиц «Затраты - Выпуск» глубокий экономический анализ. Таблицы «Затраты Выпуск» являются апробированным средством для построения макроструктурных моделей развития экономики. Методология «Затраты - Выпуск» привлекательна тем, что в рамках МОБ (межотраслевого баланса) можно добиться сбалансированности показателей динамических и структурных характеристик развития экономики.

Первая завершенная модель МОБ построена в 1930-е годы В. Леонтьевым ${ }^{5}$. Экономистами 6 бывшего СССР были разработаны разнообразные варианты динамических межотраслевых моделей, их модификаций и обобщений 7 , используемых при решении многочисленных задач экономического анализа, прогнозирования и планирования, главным образом для уровней страны и отдельных регионов (Гранберг, 1985).

История развития межотраслевого подхода характеризуется непрерывным ростом масштабов работ и разнообразием их направлений ${ }^{8}$ (Баранов, Пионтковский, Старицына, 2019; Масакова, 2019; Аксень, 2019; Быков, Роднянский, Хаустович, Шутилин, 2019).

В современной научной литературе представлены два основных направления моделирования экономической динамики на основе МОБ. Первое опирается на построение традиционных динамических моделей МОБ, которые по способу взаимо-

${ }^{5}$ Отдельные элементы моделей МОБ встречались еще в конце XIX - начале XX вв. в исследованиях швейцарского экономиста Л. Вальраса и русского экономиста В.К. Дмитриева.

${ }^{6}$ Следует отметить, что разработка и внедрение МОБ в практику под руководством А.Н. Ефимова и при участии Э.Ф. Баранова, Э.Б. Ершова, Ф.Н. Клоцвога, В.В. Коссова, С.С. Шаталина и других исследователей были высоко оценены - Государственной премией СССР.

7 Авторы наиболее известных моделей: Э.Ф. Баранов, А.Г. Гранберг, Ф.Н. Клоцвог, Б.М. Смехов, Я.М. Уринсон, Н.Ф. Шатилов.

8 Специальный выпуск журнала «Проблемы прогнозирования» № 6 за 2018 г. (основные статьи выпуска Ивантер; Алмон; Широв; Бардацци, Гецци; Баранов, Павлов, Слепенкова, Тагаева). увязки условий экономического развития между отрезками времени разделяются на: модели с прямой рекурсией (рекуррентные); модели с обратной рекурсией; модели с двусторонними связями отрезков времени - полностью динамические (Гранберг, 1985). Отличительной особенностью этих моделей по сравнению со статическими является выделение производственных капиталовложений из состава конечной продукции с целью учета их влияния на экономический рост в последующие периоды времени. Большинство параметров таких моделей имеют сложную природу; их формирование и обновление представляет собой наиболее трудоемкую часть работы по построению и использованию динамических моделей, особенно для средне- и долгосрочного периода. Кроме того, высока трудоемкость информационного наполнения и сопровождения данных моделей.

Несмотря на несомненные достоинства таких моделей в теоретическом плане, на практике они используются крайне редко, поскольку имеют ряд ограничений вычислительного и информационного характера (Miller, Blair, 2009; Chonghui, Huanwen, 2002; Kurz, Salvadori, 2000): неустойчивость получаемых решений, их высокая чувствительность к изменению входных данных и способу решения динамической задачи; наличие инвестиционного лага, корректное описание которого осложняется трудностями с определением его величины по отраслям и видам инвестиций, разделением производственных мощностей на «старые» и «новые», определением степени их загрузки, учетом неравномерности динамики параметров ввода и выбытия основных средств по периодам; предположение о неизменности во времени матриц коэффициентов прямых затрат (КПЗ) и производственных капиталовложений и др.

Второе направление исследований связано с переходом от использования традиционных моделей МОБ к созданию комплексных (интегрированных) моделей, базирующихся на МОБ, оптимизационных и эконометрических методах. В последние годы на практике при прогнозировании экономики применяются в основном модели, относящиеся ко второму направлению. К 
таким моделям относятся INFORUM ${ }^{9}$ (Wang, 2000; Алмон, 2016), RIM ${ }^{10}$ (Широв, Янтовский, 2017), агент-ориентированные межрегиональные модели «Затраты - Выпуск» (Суслов, Доможиров, Ибрагимов, Костин, Мельникова, Цыплаков, 2016), проекты EORA (Lenzen, Moran, Kanemoto, Geschke, 2013) и WIOD (Dietzenbacher, Los, Stehrer, Timmer, Vries, 2013). Например, глобальная модель INFORUM ${ }^{11}$ состоит из балансово-эконометрических моделей 20 национальных экономик с использованием МОБ, 12 из которых взаимосвязаны на основе модели внешней торговли. Проекты EORA и WIOD направлены на формирование межстрановых сбалансированных МОБ, в которые вошли 197 и 40 стран соответственно.

В НИЭИ Министерства экономики Республики Беларусь также накоплен определенный опыт построения и использования экономико-математических моделей на основе МОБ. Для нахождения отраслевой структуры белорусской экономики были разработаны двухкритериальная модель максимизации валового внутреннего продукта (ВВП) и минимизации потребления топливно-энергетических ресурсов (ТЭР) (Кравцов, Пашкевич, Подкопаев, 2002), трехкритериальная модель максимизации ВВП, минимизации потребления ТЭР и максимизации внешнеторгового сальдо (Кравцов, Пашкевич, 2004), четырехкритериальная модель (Кравцов, Крукова, 2005),

${ }^{9}$ Проект INFORUM (Interindustry Forecasting Project at the University of Maryland) - объект сотрудничества специалистов из двух десятков стран в области межотраслевого моделирования и прогнозирования. Основателем и лидером проекта является профессор университета штата Мериленд (США) Клоппер Алмон.

${ }^{10}$ RIM (Russian Interindustry Model) - название для российской межотраслевой модели, построенной Институтом народнохозяйственного прогнозирования РАН на принципах сообщества INFORUM.

${ }^{11}$ C 1993 г. ежегодно проводится Международная научная конференция по межотраслевому моделированию INFORUM (Inforum World Conference). Последняя (XXVII) на данный момент конференция проводилась 2-6 сентября 2019 г. в г. Сочи (Российская Федерация). В работе конференции приняли участие исследователи из 9 стран: США, Китая, ЮАР, Германии, Польши, Италии, Чили, Японии, России. В представленных на конференцию докладах участников обращалось внимание на широкие возможности межотраслевых моделей, их значимость для государственного регулирования, стратегического планирования и прогнозирования приоритетных направлений развития экономики. которая помимо трех вышеназванных критериев содержит критерий минимизации выбросов углекислого газа, образующегося при сжигании топлива. В рамках второго направления разработаны динамические межотраслевые модели прогнозирования основных показателей социально-экономического развития Республики Беларусь:

- балансово-оптимизационная (Кравцов, Антаневич, 2015а; Кравцов, 2017) и ее модификация (Кравцов, Антаневич, 2015b);

- балансово-эконометрическая (Кравцов, Лазовский, Федченко, 2018; Кравцов, Гладкая, 2019);

- двухэтапная балансово-оптимизационная (Кравцов, 2016).

Данные модели связаны с реализацией новых возможностей, открывающихся в результате исключения переменных, характеризующих КПЗ, из набора экзогенных показателей. Так, в балансово-эконометрической модели элементы матрицы КПЗ прогнозируются на основе неструктурных моделей, а в балансово-оптимизационной модели КПЗ наряду с объемными показателями конечной продукции, промежуточного потребления, промежуточных затрат и валовыми добавленными стоимостями по укрупненным агрегатам рассматриваются как единая органическая часть моделируемого объекта и включаются в число эндогенных переменных.

Методические вопросы, связанные с разработкой вариантов прогноза важнейших показателей социально-экономического развития Республики Беларусь на 2019 г. в зависимости от изменения отраслевой структуры экономики на основе динамических межотраслевых моделей (балансово-эконометрической и балансово-оптимизационной) рассматриваются в работе ${ }^{12}$. Балансово-эконометрическая межотраслевая модель применялась при разработке проекта Прогноза основных параметров социально-экономического развития Республики Беларусь на 2019-2020 гг.

${ }_{12}$ Кравцов М.К. 2018. Методические основы разработки вариантов прогноза макропоказателей белорусской экономики с использованием динамических межотраслевых моделей. Проблемы прогнозирования и государственного регулирования социально-экономического развития: материалы XIX Международной научной конференции. Минск: НИЭИ Министерства экономики Республики Беларусь. Т. 1. С. 107-114. 


\section{Совериенствование и развитие динамической балансово- әконометрической межотраслевой модели}

Динамическая балансово-эконометрическая межотраслевая модель реализована с использованием пакета EViews в форме модельного комплекса (Кравцов, Лазовский, Федченко, 2018; Кравцов, Гладкая, 2019) в разрезе укрупненных агрегатов, состоящего из:

эконометрических моделей прогнозирования элементов матрицы КПЗ, в основе которых лежит неструктурный подход, подтвердивший гипотезу о том, что высокая волатильность КПЗ в Республике Беларусь от года к году объясняется структурными сдвигами, связанными, главным образом, с изменением методических подходов к расчету показателей МОБ, тогда как магистральное направление их движения подчиняется общим трендам, отражающим, в частности, естественный ход научно-технического прогресса и связанные с этим изменения в межотраслевых связях;

авторегрессионной модели прогнозирования чистых налогов на продукты на использованные товары в составе промежуточных затрат и конечной продукции;

эконометрических моделей прогнозирования показателей валовых выпусков по укрупненным агрегатам, а также конечного потребления, валового накопления, экспорта и импорта товаров и услуг по республике.

Динамика в моделях обеспечивается за счет лаговых переменных, а также динамики взаимосвязи капиталовложений и валовых выпусков агрегатов, отражаемых в разработанных эконометрических уравнениях.

Методология прогнозирования основных показателей социально-экономического развития Республики Беларусь на основе балансово-эконометрической межотраслевой модели изложена в работе $\mathrm{e}^{13}$.

В данном разделе представлена расширенная версия балансово-эконометрической межотраслевой модели с учетом включения

13 Кравцов М.К. 2017. Методология прогнозирования основных макропоказателей белорусской экономики на основе динамических межотраслевых моделей. Проблемь прогнозирования и государственного регулирования соииально-экономического развития: материалы XVIII Международной научной конференции. Минск: НИЭИ Министерства экономики Республики Беларусь Т. 1. С. 160-170. основных элементов валовой добавленной стоимости, являющихся объектами исследования в настоящей работе. В этой версии также представлены переоцененные, а некоторые из них и усовершенствованные эконометрические модели прогнозирования КПЗ, валовых выпусков в разрезе агрегатов и основных элементов конечного спроса по республике.

Информационная база модели. В основу информационной базы положены отчетные МОБ производства и использования товаров и услуг Республики Беларусь за период 1996-2017 гг. (таблицы «Затраты - Выпуск»), публикуемые Национальным статистическим комитетом Республики Беларусь. При формировании информационной базы возникает ряд проблем, которые связаны с переходом от цен покупателей к основным ценам (2003 г.); изменением методик формирования таблиц (переход в 2011 г. от Общесоюзного классификатора отраслей народного хозяйства (ОКОНХ) к Общегосударственному классификатору Республики Беларусь «Виды экономической деятельности» (ОКРБ 0052006) и в 2016 г. к новой версии ОКЭД (ОКРБ 005-2011)); расширением отражаемого отраслевого состава секций; перевод показателей из текущих цен в сопоставимые; отсутствие оперативной информации (отчетный баланс в Республике Беларусь представляется с опозданием в полтора года после окончания отчетного периода). В силу несопоставимости данных до 2010 г. (согласно номенклатуре ОКОНХ) с данными 2011 г. (согласно номенклатуре ОКЭД) целесообразным представляется создание 6 укрупненных агрегатов ${ }^{14}$ : «Промышленность»; «Строительство»; «Сельское, лесное и рыбное хозяйство»; «Транспорт, информация и связь»; «Торговля, ремонт автомобилей и мотоциклов, услуги по временному проживанию и питанию»; «Прочие услуги» (Кравцов, Борейко, Никитина, 2014).

В 2016 г. произошло расширение номенклатуры с 31 до 83 видов экономической дея-

14 Здесь и далее агрегаты пронумерованы следующим образом: 1 - «Промышленность»; 2 - «Строительство»; 3 - «Сельское, лесное и рыбное хозяйство»; 4 «Транспорт, информация и связь»; 5 - «Торговля, ремонт автомобилей и мотоциклов, услуги по временному проживанию и питанию»; 6 - «Прочие услуги». 
тельности (ВЭД). После сопоставления МОБ 2015 и 2016 гг. состав агрегатов (по версии ОКРБ 005-2011) имеет следующий вид: «Промышленность» - секции В-E (коды направлений 05-39); «Строительство» - секция $\mathrm{F}$ (41-43); «Сельское, лесное и рыбное хозяйство»- секция А (01-03); «Транспорт, информация и связь»- секции Н и $\mathrm{J}$ (49-53, 58-63; 85); «Торговля, ремонт автомобилей и мотоциклов, услуги по временному проживанию и питанию» - секции G и I (45-47, 5556; 84); «Прочие услуги» - секции K-S (6496). Коды направлений 84 и 85 (агрегаты 4, 5) представляют собой торговую и транспортную наценки на использованные товары.

При выделении составляющих III квадранта МОБ возникают сложности, обусловленные недостатком статистической информации. В таблицах «Затраты - Выпуск» 2017 г. в третьем квадранте представлены: оплата труда работников; другие налоги на производство; другие субсидии на производство; потребление основного капитала; чистая прибыль и чистый смешанный доход. Проведение агрегации данных показателей в исходном виде на промежутке 1996-2017 гг. невозможно из-за несопоставимости данных разных годов. Так, до 2014 г. не выделялись отдельно показатели чистой прибыли и чистого смешанного дохода и потребления основного капитала, которые в сумме представляют величину валовой прибыли и валового смешанного дохода. Похожая ситуация и с показателями «Другие налоги на производство» и «Другие субсидии на производство». На промежутке 2011-2015 гг. в таблицах приводится лишь один показатель - «Другие налоги на производство за вычетом субсидий». В связи с этим, в III квадранте МОБ выделены следующие показатели: оплата труда работников, валовая прибыль и валовой смешанный доход, другие налоги на производство за вычетом субсидий.

В результате, на основе МОБ сформированы временные ряды (В. р.) годовой периодичности за 1996-2017 гг. в белорусских рублях и долларах США ${ }^{15}$ в разрезе 6 агрегатов: КПЗ; чистые налоги на продукты; вало-

15 Все В. р. в белорусских рублях переведены в доллары США для того, чтобы исключить инфляцию из номинальных величин и не нарушить балансовые соотношения между показателями. вые выпуски (ВВ); валовые добавленные стоимости (ВДС); оплата труда работников, валовая прибыль и валовой смешанный доход, другие налоги на производство за вычетом субсидий, а также на уровне республики (конечное потребление домашних хозяйств (ДХ) и некоммерческих организаций, обслуживающих ДХ; конечное потребление государственных учреждений; конечное потребление; валовое накопление основного капитала; изменение запасов материальных оборотных средств). В качестве значений всех В. р. (кроме КПЗ) за 2018 г. использованы данные, опубликованные Национальным статистическим комитетом Республики Беларусь ${ }^{16}$. Стоит отметить, что статистическое расхождение при расчете ВВП методом использования доходов на основе предварительных данных в 2018 г. составляет 1360,2 млн руб., или 0,62\% от его фактического значения. В табл. 1 представлены условные обозначения сформированных В. р. годовой периодичности, а также других показателей, используемых в моделях.

В системе таблиц «Затраты - Выпуск» нет разделения экспорта (импорта) на экспорт (импорт) товаров и услуг, поэтому В. p. показателей «Экспорт товаров», «Импорт товаров», «Экспорт услуг», «Импорт услуг» за 2000-2018 гг. сформированы на основе данных из Платежного баланса Республики Беларусь ${ }^{17}$, а в период 1996-1999 гг. дополнены данными из сборника «Внешняя торговля Республики Беларусь» ${ }^{18}$. Необходимо отметить, что статистическая информация, приведенная в таблицах «ЗатратыВыпуск», отличается от данных из других источников, но из-за отсутствия другой доступной статистики, при построении моделей использовались данные платежного баланса и сборника «Внешняя торговля».

Информация о номинальных курсах белорусского рубля к иностранным валютам (среднее геометрическое значение) $)^{19}$, а также

${ }^{16}$ URL: https://www.belstat.gov.by/ofitsialnaya-statistika/ publications/izdania/public_compilation/index_16642/

${ }^{17}$ URL: https://www.nbrb.by/statistics/balpay

${ }^{18}$ URL: https://www.belstat.gov.by/ofitsialnaya-statistika/ publications/katalog/vneshnyaya-torgovlya-respubliki-belarus/

${ }^{19}$ Средний официальный курс белорусского рубля по отношению к иностранным валютам 2004-2019 гг. URL: http:/ /www.nbrb.by/statistics/rates/avgrate; Значения за 19962003 гг. рассчитаны на основе данных о ежедневных курсах. URL: https://www.nbrb.by/statistics/rates/ratesdaily.asp 
Условные обозначения и единицы измерения В. р., используемых

в балансово-эконометрической модели

\begin{tabular}{|c|c|}
\hline $\begin{array}{c}\text { Условное } \\
\text { обозначение } \\
\text { В. р. }\end{array}$ & Показатель \\
\hline$a_{i t}$ & Среднесписочная численность занятых в $i$-м агрегате, тыс. чел. \\
\hline budexp & Расходы консолидированного бюджета, млн руб. \\
\hline$c e_{i t}$ & Оплата труда работников $i$-го агрегата, тыс. руб. \\
\hline$c i_{t}$ & Изменение запасов материальных оборотных средств, тыс. руб. \\
\hline $\mathrm{conn}_{t}$ & Доходы от услуг связи, млн руб. \\
\hline$e n_{t}$ & Потребление электроэнергии, млрд кВт·ч \\
\hline$f a_{3 t}$ & Основные средства в агрегате «Сельское, лесное и рыбное хозяйство», млн руб. \\
\hline$f c_{t}$ & Конечное потребление, тыс. руб. \\
\hline$f c g_{t}$ & Конечное потребление государственных учреждений, тыс. руб. \\
\hline$f c h n_{t}$ & Конечное потребление ДХ и некоммерческих организаций, обслуживающих ДХ, тыс. руб. \\
\hline gasp & Цена импорта природного газа, долл. США/1000 м³ \\
\hline gdpru & ВВП России, млн долл. США \\
\hline$g f c f_{t}$ & Валовое накопление основного капитала, тыс. руб. \\
\hline$g v a_{i t}$ & Валовая добавленная стоимость $i$-го агрегата, тыс. руб. \\
\hline$i n v_{t}$ & Инвестиции в основной капитал, тыс. руб. \\
\hline$l p_{i t}$ & Производительность труда по ВДС в $i$-ом агрегате, млн руб/чел. \\
\hline$M G_{t}$ & Импорт товаров, млн долл. США \\
\hline$M I N C_{t}$ & Денежные доходы населения, млн руб. \\
\hline$M S_{t}$ & Импорт услуг, млн долл. США \\
\hline$N T_{i t}$ & Чистые налоги на продукты в $i$-м агрегате, тыс. руб. \\
\hline$n r_{t}$ & Ставка рефинансирования, \% \\
\hline$n w_{t}$ & Номинальная начисленная среднемесячная заработная плата, руб. \\
\hline oilp & Цена импорта сырой нефти, долл. США/т \\
\hline onpt $_{i t}$ & Другие налоги на производство за вычетом субсидий $i$-го агрегата, тыс. руб. \\
\hline$R T_{t}$ & Розничный товарооборот, млрд руб. \\
\hline$R U R R_{t}$ & Реальный курс белорусского рубля к российскому рублю, руб/рос. руб. \\
\hline$U S D_{t}$ & Номинальный курс белору сского рубля к доллару США, руб/долл. США \\
\hline Vocw $_{t}$ & Объем подрядных работ, млрд руб. \\
\hline$W R_{t}$ & Номинальная тарифная ставка первого разряда, руб. \\
\hline$x_{i t}$ & ВВ $i$-го агрегата, тыс. руб. \\
\hline$X G_{t}$ & Экспорт товаров, млн долл. США \\
\hline$X G S_{t}$ & Экспорт товаров и услуг, млн долл. США \\
\hline$X S_{t}$ & Экспорт услуг, млн долл. США \\
\hline
\end{tabular}

Источник. Авторская разработка.

показатель «Ставка рефинансирования» ${ }^{20}$ предоставлены Национальным банком Республики Беларусь. Реальный курс белорус-

${ }^{20}$ Ставка рефинансирования рассчитывалась как среднегодовое значение на основе информации: URL: https:// www.nbrb.by/statistics/monetarypolicyinstruments/refinan cingrate? $\mathrm{m}=$ stat ского рубля к российскому вычислен на основе номинального курса белорусского рубля к российскому рублю и индексов потребительских цен в Республике Беларусь и Российской Федерации. Источником данных о ВВП России послужила информация Все- 
мирного банка ${ }^{21}$; цены импорта сырой нефти и природного газа опубликованы в сборнике «Внешняя торговля Республики Беларусь». Статистическая информация по остальным показателям, перечисленным в табл. 1, представлена в статистических ежегодниках Национального статистического комитета Республики Беларусь.

Эконометрический анализ временных рядов и проблемы, возникающие при их прогнозировании. Основные проблемы, связанные с разработкой балансово-эконометрической межотраслевой модели для белорусской экономики, можно сформулировать следующим образом:

- короткая длина временных рядов. При построении названной модели используются годовые данные отчетных МОБ Республики Беларусь за период с 1996 по 2017 г. в силу существенной специфики макроэкономических процессов в более ранний период, а также меньшей надежности соответствующих статистических показателей;

- нестационарность анализируемых В. р. макроэкономических показателей (Малюгин, 2014), т. е. изменчивость их вероятностных характеристик (математическое ожидание, дисперсия, ковариационная функция) во времени;

- подверженность краткосрочной динамики многих макроэкономических индикаторов структурным изменениям. В связи с этим представляется целесообразным введение в эконометрические зависимости фиктивных переменных, отражающих специфический эффект того или иного структурного изменения (Кравцов, Пашкевич, Бурдыко, 2005). К таким переменным относятся: $D U(\cdot)_{t}$ и $D T(\cdot)_{t}$ - соответственно фиктивные переменные, отражающие изменение уровня ряда и тренда на некотором промежутке, $D(\cdot)_{t}-$ фиктивная переменная, обозначающая выброс в некотором году;

- особенности подготовки и представления данных органами официальной статистики. К их числу можно отнести пропуски, изменения методик исчисления и представления сопоставимых значений для некоторых макроэкономических показателей;

${ }^{21}$ GDP (current US\$) - Russian Federation. URL: https:/ /data.worldbank.org/indicator/NY.GDP.MKTP.CD? locations $=\mathrm{RU}$
- существенная задержка времени поступления макроданных, которая обусловливает необходимость расширения горизонта прогнозирования на период задержки.

С целью проверки свойства стационарности, определения порядка интегрированности для нестационарных рядов, выявления других особенностей моделей (Малюгин, 2014) проведен предварительный статистический анализ В. p. Тестирование и определение порядка интегрированности проводилось с помощью реализованных в EViews тестов - расширенного ДикиФуллера (ADF-тест) и Квятковского-Филлипса-Шмидта-Шина (KPSS-тест). В тесте ADF в качестве нулевой гипотезы принимается предположение о наличии единичного корня, а в тесте KPSS - отсутствии стохастического тренда. Результаты ADF- и KPSS-тестов свидетельствуют о том, что все рассматриваемые В. р. являются нестационарными на временном промежутке 19962018 гг. Поэтому для всех В. р. применен оператор взятия разностей $(\Delta)$, а затем при помощи тех же тестов произведена проверка В. р. в разностях на стационарность. Результаты тестов свидетельствуют в пользу предположения о стационарности первых разностей всех рассматриваемых рядов ${ }^{22}$.

Заметим, что за исключением некоторых случаев, исходные статистические данные, используемые для построения эконометрических моделей, должны быть представлены В. р. экономических индексов, т. е. относительными (и, следовательно, безразмерными) величинами. Обусловлено это требование необходимостью согласования во многих уравнениях размерностей показателей, имеющих разные единицы измерения. Если же используются данные, не являющиеся безразмерными, то для корректной математической записи уравнений эти данные должны быть пронормированы. Нормировочными коэффициентами могут служить, например, исходные данные в базисном году или их единицы измерения. В нашей работе в качестве нормировочных

22 Полученные результаты отличаются от предыдущих: после увеличения числа наблюдений ранее нестационарные первые разности логарифмических В. р. «ВВ в сельском, лесном и рыбном хозяйстве», «Цена импорта природного газа», «Номинальный курс белорусского рубля к доллару США» по результатам тестов можно отнести к стационарным. 
коэффициентов взяты единицы измерения соответствующих показателей. Они позволяют содержательно интерпретировать каждое уравнение из разработанной балансово-эконометрической межотраслевой модели и провести анализ получаемых на ее основе выводов.

В экономических исследованиях наиболее широко используется мультипликативная форма представления функциональной зависимости моделируемой переменной от значений независимых переменных, и в таких случаях при построении моделей удобно пользоваться логарифмическим масштабом (при записи обозначается как $\ln (\cdot))$. В этом случае параметры (коэффициенты) уравнений имеют смысл эластичностей.

При оценке качества построенных моделей использовались следующие статистические характеристики и тесты: коэффициент детерминации $\left(R^{2}\right)$, скорректированный коэффициент детерминации $\left(R_{a}^{2}\right)$; стандартная ошибка регрессии $(S E R)$; статистика Дарбина-Уотсона $(D W)$; тест Жака-Бера $(J B)$ на нормальность распределения остатков; тест Бреуша-Годфри $(B G)$ на наличие автокорреляции в остатках; тесты Уайта $(W)$ и Бреуша-Пагана-Годфри $(B P G)$ на гетероскедастичность остатков.

Основные подходы к прогнозированию

кП3. Первоначальная гипотеза В. Леонтьева о неизменности КПЗ, составляющих матрицу МОБ, в итоге не оправдалась. Например, изменения матрицы КПЗ в Республике Беларусь от года к году значительны. Среднее относительное отклонение их матриц за 2011-2012 гг. в разрезе 30 видов ЭД составило 23,88\%. Нестабильность коэффициентов исключает возможность использования последней имеющейся матрицы КПЗ в модельных расчетах, поскольку ее использование может приводить к высокой погрешности прогнозируемых показателей. Поэтому возникает проблема прогнозирования КПЗ, имеющих ключевое значение для прогнозных расчетов.

Разработке подходов к прогнозированию КПЗ посвящено большое число публикаций. Для анализа качества оптимизационных моделей с различными критериями (энтропийным, квадратичным, минимаксным, суммы модулей отклонений),
RAS-метода ${ }^{23}$ и модифицированного RAS-метода ${ }^{24}$, а также возможностей их применения для прогнозирования будущих значений КПЗ проведены вычислительные эксперименты на информации отчетных МОБ за 2004-2010 гг. (Кравцов, Антаневич, Безрукова, 2014). По результатам проведенных экспериментов сделаны следующие выводы: модель с энтропийным критерием имеет приемлемую точность прогноза, а использование модифицированного RAS-метода является более обоснованным по сравнению с RAS-методом. Однако, прогнозирование КПЗ с помощью этих средств проводится исходя из базовой матрицы КПЗ и заданных векторов ВВ, ПП и промежуточных затрат по отраслям для прогнозного года.

Среди более поздних исследований следует указать работы, которые по сравнению с другими менее требовательны к наличию входной информации и, по-видимому, являются наиболее перспективными для прогнозирования КПЗ: 1) неструктурные эконометрические модели (Никитина, 2018; Кравцов, Гладкая, 2019); 2) расширенная версия метода Хорафаса (Кравцов, Лазовский, 2018); 3) методика корректировки важных коэффициентов (Саяпова, Сыртланов, Широв, 2015).

В основе балансово-эконометрической межотраслевой модели лежит система из 36 неструктурных эконометрических моделей прогнозирования элементов матрицы КПЗ, которые первоначально были предложены в работе А.К. Никитиной (2018). В качестве переменных в предлагаемых моделях используются компоненты авторегрессии, скользящего среднего, фиктивные переменные (задающие выброс в году $t$, изменения уровня ряда и тренда), константа, тренд. Построение моделей осуществлялось на информации отчетных МОБ 1996-2015 гг. в разрезе 6 укрупненных агрегатов. После переоценки исходных моделей на 1996-2017 гг. было принято решение о внесении изменений в состав переменных для некоторых моделей и пост-

${ }^{23}$ Немет Ш. 1971. Сводная информация о применении метода RAS. Будапешт. 283 с.

24 Модифицированный RAS-метод в отличие от RAS-метода учитывает фиксирование некоторых элементов матрицы КПЗ. 
роении новых. Основанием для этого послужили высокие ошибки прогнозирования матрицы КПЗ, ее отдельных элементов (отклонение прогнозных матриц от фактических составили 20,10 и 16,88\% в 2016 и 2017 гг. соответственно), которые могут возникнуть в силу ряда причин, описанных в работе (Кравцов, Гладкая, 2019).

В работе (Саяпова, Сыртланов, Широв, 2015) изложена методика, с помощью которой существует возможность рассчитать предельные отклонения для каждого элемента матрицы КПЗ, задавая темпы приростов ВВ.

Альтернативным способом прогнозирования матрицы КПЗ является использование расширенной версии метода Хорафаса. В основе данной версии, как и в методе Хорафаса ${ }^{25}$, лежит предположение о том, что анализируемые данные образуют однородную марковскую цепь, которая однозначно определяется своим начальным распределением и матрицей переходных вероятностей. В этой версии в качестве входной информации используются фактические данные о КПЗ за ряд лет, предшествующих прогнозному периоду. Подробное изложение расширенной версии метода Хорафаса приведено в работе (Кравцов, Лазовский, 2018). Отметим, что применение данной версии дало несколько лучшие результаты в сравнении с неструктурными эконометрическими моделями: отклонения прогнозных матриц от фактических составили 9,06 и 5,15\% в 2016 и 2017 гг. соответственно.

\section{Усовершенствованные эконометричес- кие модели прогнозирования валовых вы-} пусков в разрезе агрегатов. Эконометрические модели для прогнозирования ВВ в разрезе агрегатов оценены на статистических годовых данных 1996-2016 гг. (Кравцов, Лазовский, Федченко, 2018). Несмотря на приемлемые статистические характеристики и хорошие прогностические способности разработанных моделей, возникает необходимость в их пересмотре из-за наличия лаговых переменных больших порядков, которые сложно интерпретировать с экономической точки зрения. Исключение лаговых переменных повлекло изменения

25 Хорафас Д.Н. 1967. Системы и моделирование. Москва: Мир. 420 с. в спецификации большинства уравнений. Значительные изменения произошли в уравнении ВВ сельского, лесного и рыбного хозяйства, которое построено в первых разностях, что согласуется с результатами тестов на стационарность (разработанное ранее уравнение было построено во вторых разностях).

Важнейшими факторами, оказывающими влияние на ВВ промышленности, являются потребление электроэнергии, ВВП России (как одного из основных торговых партнеров Республики Беларусь), цена импорта природного газа. Рост ВВ строительства определяется инвестициями в основной капитал, которые занимают значительный удельный вес в валовом накоплении основного капитала. ВВ сельского, лесного и рыбного хозяйства включает в себя продукцию и услуги, произведенные, в том числе, для конечного потребления, поэтому важным фактором, определяющим ВB, является конечное потребление. К тому же продукция данной отрасли востребована не только на внутреннем рынке, но и за пределами страны, поэтому существенное влияние на эту сферу оказывает объем экспорта товаров Республики Беларусь. В качестве основных факторов, определяющих динамику ВВ транспорта, информации и связи выбраны валовое накопление основного капитала и доходы от услуг связи, отражающие интенсивности работы отрасли. При моделировании ВВ торговли, ремонта автомобилей и мотоциклов, услуг по временному проживанию и питанию используются показатели конечное потребление и ВВП России. Факторами, влияющими на ВВ прочих услуг, являются конечное потребление и экспорт услуг.

Усовершенствованные модели прогнозирования ВВ в разрезе агрегатов, оцененные на промежутке за 1996-2017 гг., имеют следующий вид:

$$
\begin{aligned}
& \Delta \ln \left(x_{1 t}\right)=4,765 \Delta \ln \left(e n_{t}\right)+0,367 \Delta \ln \left(\text { gdpru }_{t}\right)+ \\
& +0,247 \Delta \ln \left(\text { gasp }_{t}\right)-0,172 D(2001)_{t}- \\
& -0,193 D(2003)_{t}-0,295 D(2010)_{t}
\end{aligned}
$$

$\Delta \ln \left(x_{2 t}\right)=1,063 \Delta \ln \left(g f c f_{t}\right)-0,187 D(2003)_{t}-$ $-0,188 D(2011)_{t}-0,120 D(2016)_{t}$; 
$\Delta \ln \left(x_{3 t}\right)=1,009 \Delta \ln \left(f c_{t}\right)+0,140 \Delta \ln \left(X G_{t}\right)-$

$-0,051+0,159 D(2010)_{t}$;

$\Delta \ln \left(x_{4 t}\right)=0,488 \Delta \ln \left(g f f_{t}\right)+0,231 \Delta \ln \left(\right.$ conn $\left._{t}\right)+$

$+0,272 D(2016)_{t}$;

$\Delta \ln \left(x_{5 t}\right)=0,732 \Delta \ln \left(f \mathcal{C}_{t}\right)+0,303 \Delta \ln \left(g d p r u_{t}\right)+$

$+0,279 D(1998)_{t}-0,130 D(2001)_{t}+$

$+0,214 D(2011)_{t}-0,011$;

$\Delta \ln \left(x_{6 t}\right)=0,204 \Delta \ln \left(X S_{t}\right)+0,716 \Delta \ln \left(f c_{t}\right)+$

$+0,117 D(2011)_{t}-0,111 D(2016)_{t}$.

Оценки коэффициентов в приведенных уравнениях статистически значимы на уровне 0,05 за исключением коэффициента при показателе «Экспорт товаров» в уравнении (3), который значим на уровне 0,1 . Основные статистические характеристики уравнений (1) - (6) приведены в табл. 2.

Для уравнений (1) - (6) проведена проверка их прогностической способности на ретроспективе. Относительные погрешности прогнозирования ВВ по агрегатам в 2017 г. составили соответственно: 1,48\%; $0,86 \% ; 6,33 \% ; 6,35 \% ; 1,80 \% ; 5,56 \%$.

Модифицированные эконометрические модели прогнозирования основных элементов конечного использования по республике. Эконометрические модели прогнозирования основных элементов конечного использования, ранее разработанные в НИЭИ Министерства экономики Республики Беларусь, так же, как и модели для ВВ, подверглись модификации с целью исключения лаговых переменных больших порядков (в частности, уравнения для показателей «Инвестиции в основной капитал», «Изменение запасов материальных оборотных средств»,
«Импорт услуг»). Изменению также подверглись модели экспорта товаров и услуг и денежных доходов населения, включающие вторые разности показателя «Номинальный курс белорусского рубля к доллару США». При повторном тестировании гипотеза о стационарности первых разностей данного показателя не отклоняется на 10\%-м уровне значимости. Поэтому в уравнениях для экспорта товаров и услуг вторые разности В. р. «Номинальный курс белорусского рубля к доллару США» заменены на первые (при подстановке в уравнение прогнозирования денежных доходов населения переменная оказалась незначимой, поэтому исключена из рассмотрения).

Основными факторами, определяющими конечное потребление ДХ и некоммерческих организаций, обслуживающих ДХ, являются денежные доходы населения. Для прогнозирования денежных доходов населения используется такой фактор, как среднемесячная заработная плата. В качестве основного фактора, влияющего на конечное потребление государственных учреждений, выбран показатель «Расходы консолидированного бюджета».

Динамика валового накопления основного капитала зависит от инвестиций в основной капитал и импорта товаров. Для прогнозирования инвестиций в основной капитал выбраны такие экзогенные переменные, как номинальная ставка рефинансирования и инвестиции в основной капитал с лагом 1 год. При моделировании изменения запасов материальных оборотных средств используется авторегрессионная модель.

Для прогнозирования экспорта товаров и услуг выбраны такие факторы, как

Таблица 2

Значения критериев оценки качества регрессионных уравнений (1) - (6)

\begin{tabular}{|c|c|c|c|c|c|c|c|}
\hline № уравнения & $R^{2}$ & $R_{a}^{2}$ & $S E R$ & $D W$ & $J B$ & $B G$ & $W$ \\
\hline$(1)$ & 0,926 & 0,901 & 0,064 & 2,229 & $1,181(0,554)$ & $1,241(0,321)$ & $0,423(0,852)$ \\
\hline$(2)$ & 0,956 & 0,949 & 0,058 & 1,980 & $0,412(0,814)$ & $0,148(0,863)$ & $0,549(0,702)$ \\
\hline$(3)$ & 0,902 & 0,884 & 0,065 & 2,215 & $1,076(0,583)$ & $0,854(0,446)$ & $0,510(0,681)$ \\
\hline$(4)$ & 0,842 & 0,825 & 0,062 & 1,771 & $1,070(0,586)$ & $1,434(0,266)$ & $0,764(0,529)$ \\
\hline$(5)$ & 0,936 & 0,916 & 0,055 & 1,748 & $0,038(0,981)$ & $0,578(0,573)$ & $0,282(0,916)$ \\
\hline$(6)$ & 0,961 & 0,954 & 0,031 & 1,848 & $1,297(0,523)$ & $0,007(0,993)$ & $1,188(0,353)$ \\
\hline
\end{tabular}

Примечание. Здесь и далее в таблицах в скобках указаны $p$-значения соответствующих статистик.

Источник. Авторская разработка. 
Прогнозирование основных параметров социально-экономического развития Республики Беларусь

ВВП России и номинальный курс белорусского рубля к доллару США. При моделировании импорта товаров учитываются такие экзогенные переменные, как конечное потребление ДХ и некоммерческих организаций, обслуживающих ДХ, цена импорта сырой нефти, экспорт товаров. Экзогенными переменными, использовавшимися для определения импорта услуг, являются денежные доходы населения, реальный курс белорусского рубля к российскому рублю.

Система эконометрических уравнений для прогнозирования основных элементов конечного использования в Республике Беларусь, оцененная на статистических годовых данных за 1996-2017 гг., имеет вид: экспорт товаров -

$\Delta \ln \left(X G_{t}\right)=0,720 \Delta \ln \left(g d p r u_{t}\right)-0,159 \Delta \ln \left(U S D_{t}\right)-$ $-0,220 D(2009)_{t}+0,315 D(2011)_{t}-0,293 D(2013)_{t}$;

инвестиции в основной капитал -

$\Delta \ln \left(i n v_{t}\right)=0,393 \Delta \ln \left(i n v_{t-1}\right)-0,437 \Delta \ln \left(n r_{t}\right)-$

$-0,500 D(2001)_{t}-0,433 D(2015)_{t}$;

денежные доходы населения $\Delta \ln \left(M I N C_{t}\right)=1,131 \Delta \ln \left(n w_{t}\right)-0,075 D(2004)_{t}+$ $+0,073 D(2009)_{t}$;

конечное потребление ДХ и некоммерческих организаций, обслуживающих ДХ $\Delta \ln \left(f_{c h n_{t}}\right)=0,731 \Delta \ln \left(M I N C_{t}\right)-0,136 D(2001)_{t}-$

$-0,167 D(2012)_{t}$;

конечное потребление государственных учреждений -

$\Delta \ln \left(f_{c} g_{t}\right)=0,705 \Delta \ln \left(\right.$ budexp $\left._{t}\right)+0,297 D(2010)_{t} ;(11)$

импорт товаров -
$\Delta \ln \left(M G_{t}\right)=0,297 \Delta \ln \left(f c h n_{t}\right)+0,111 \Delta \ln \left(\right.$ oilp $\left._{t}\right)+$

$+0,673 \Delta \ln \left(X G_{t}\right)-0,148 D(2005)_{t}$;

валовое накопление основного капитала -

$\Delta \ln \left(g f c f_{t}\right)=0,789 \Delta \ln \left(i n v_{t}\right)+0,168 \Delta \ln \left(M G_{t}\right)+$

$+0,076 D(1999)_{t}+0,085 D(2006)_{t}$;

экспорт услуг -

$\Delta \ln \left(X S_{t}\right)=0,358 \Delta \ln \left(g d p r u_{t}\right)-0,120 \Delta \ln \left(U S D_{t}\right)+$

$+0,197 D(2000)_{t}-0,190 D(2009)_{t}$;

импорт услуг -

$\Delta \ln \left(M S_{t}\right)=0,656 \Delta \ln \left(M I N C_{t}\right)+0,214 \Delta \ln \left(R U R R_{t}\right)+$

$+0,244 D(2006)_{t}+0,188 D(2010)_{t}$;

изменение запасов материальных оборотных средств -

$\Delta\left(c i_{t}\right)=-0,398 \Delta\left(c i_{t-1}\right)+2,265 D(2008)_{t}-$

$-2,854 D(2009)_{t}$.

Оценки параметров являются статистически значимыми на уровне 0,05 . Основные статистические характеристики уравнений (7) - (16) приведены в табл. 3.

Проведена также проверка их прогностической способности на ретроспективе. Относительные погрешности прогнозирования по основным элементам конечного использования в 2017 г. составили: конечное потребление - 0,79\%; валовое накопление - 1,38\%; экспорт товаров и услуг $2,03 \%$; импорт товаров и услуг $-0,61 \%$.

Моделирование и прогнозирование элементов валовой добавленной стоимости. При построении макроэкономических прогнозов возникает необходимость в более детальном моделировании отдельных показателей. Для

Значения критериев оценки качества регрессионных уравнений (7) - (16)

Таблица 3

\begin{tabular}{|c|c|c|c|c|c|c|c|}
\hline № уравнения & $R^{2}$ & $R_{a}^{2}$ & $S E R$ & $D W$ & $J B$ & $B G$ & $W$ \\
\hline$(7)$ & 0,947 & 0,925 & 0,065 & 2,269 & $0,365(0,833)$ & $0,533(0,603)$ & $0,778(0,584)$ \\
\hline$(8)$ & 0,575 & 0,500 & 0,186 & 2,302 & $0,404(0,817)$ & $3,282(0,066)$ & $0,386(0,816)$ \\
\hline$(9)$ & 0,980 & 0,976 & 0,029 & 2,334 & $3,371(0,185)$ & $1,141(0,344)$ & $0,357(0,785)$ \\
\hline$(10)$ & 0,868 & 0,846 & 0,063 & 1,371 & $0,268(0,874)$ & $1,187(0,332)$ & $0,356(0,785)$ \\
\hline$(11)$ & 0,835 & 0,816 & 0,067 & 2,157 & $0,276(0,871)$ & $0,415(0,667)$ & $0,494(0,618)$ \\
\hline$(12)$ & 0,958 & 0,950 & 0,046 & 1,931 & $1,270(0,530)$ & $0,260(0,774)$ & $2,793(0,062)$ \\
\hline$(13)$ & 0,975 & 0,971 & 0,040 & 2,257 & $4,083(0,130)$ & $0,799(0,467)$ & $2,005(0,139)$ \\
\hline$(14)$ & 0,861 & 0,826 & 0,063 & 2,211 & $1,362(0,506)$ & $0,204(0,818)$ & $1,552(0,238)$ \\
\hline$(15)$ & 0,737 & 0,676 & 0,103 & 2,149 & $0,867(0,648)$ & $0,862(0,449)$ & $1,973(0,163)$ \\
\hline$(16)$ & 0,590 & 0,547 & 0,276 & 2,234 & $3,958(0,138)$ & $1,445(0,263)$ & $0,340(0,716)$ \\
\hline
\end{tabular}

Источник. Авторская разработка. 
прогнозирования элементов третьего квадранта МОБ, представляющих собой компоненты ВДС, разработаны эконометрические модели показателей «Оплата труда работников» и «Другие налоги на производство за вычетом субсидий» в разрезе укрупненных агрегатов. Значения «Валовой прибыли и валового смешанного дохода» в разрезе укрупненных агрегатов рассчитываются остаточным путем, как разность между ВДС агрегата и суммарным значением оплаты труда работников и других налогов на производство за вычетом субсидий. ВДС агрегатов рассчитываются с использованием прогнозной матрицы КПЗ, а также прогнозных значений ВВ и ЧНП.

В соответствии с исследованиями, в качестве основных факторов для моделей оплаты труда работников в разрезе укрупненных агрегатов выбраны следующие показатели.

Важнейшими факторами, определяющими рост средней оплаты труда в промышленности, являются тарифная ставка первого разряда и производительность труда по ВДС в этой отрасли. На среднюю оплату труда работников в строительстве существенное влияние оказывают тарифная ставка первого разряда, производительность труда по ВДС в строительстве, а также объем подрядных работ в пересчете на одного работника. При моделировании средней оплаты труда работников для агрегата «Сельское, лесное и рыбное хозяйство» в качестве факторов учитываются валовой выпуск данного агрегата, приходящийся на одного работника, тарифная ставка первого разряда и производительность труда по ВДС для сельского, лесного и рыбного хозяйства с лагом 1 год. Оплата труда работников «Транспорта, информации и связи» зависит от ВДС данного агрегата и численности занятых в агрегате. При моделировании оплаты труда для агрегата «Торговля, ремонт автомобилей и мотоциклов, услуги по временному проживанию и питанию» используются показатели розничного товарооборота и экспорта товаров и услуг. Факторами, влияющими на среднюю оплату труда для «Прочих услуг», являются тарифная ставка первого разряда и производительность труда по ВДС данного агрегата.
Ниже приведены эконометрические модели прогнозирования оплаты труда работников в разрезе укрупненных агрегатов, оцененные на статистических годовых данных за 1996-2018 гг.:

$$
\begin{aligned}
& \Delta \ln \left(c e_{1 t} / \text { ane }_{1_{t}}\right)=0,360 D U\left(1996 \_2019\right)_{t} \cdot \Delta \ln \left(W R_{t}\right)+ \\
& +0,528 \Delta \ln \left(l_{1 t}\right)+0,206 D(2013)_{t} \text {; }
\end{aligned}
$$

$\Delta \ln \left(c e_{5 t}\right)=1,391 \Delta \ln \left(R T_{t}\right)-0,218 \Delta \ln \left(X G S_{t}\right)+$ $+0,748$ AR(3);

$\Delta \ln \left(c e_{6 t} /\right.$ ane $\left._{6 t}\right)=0,149 D U\left(1996 \_2019\right)_{t} \times \Delta \ln \left(W R_{t}\right)+$

$+0,924 \Delta \ln \left(l p_{6 t}\right)-0,124 D(2010)_{t}$,

где $D U(\cdot)_{t}$ - фиктивная переменная изменения уровня ряда на указанном промежутке, введенная для учета влияния на данном промежутке тарифной ставки первого разряда на оплату труда. Все переменные моделей статистически значимы на уровне 0,05.

Уравнения (17) - (19) и (22) предназначены для прогнозирования средней оплаты труда, приходящейся на одного занятого в агрегатах, в то время как уравнения (20) и (21) отражают оплату труда в целом.

В табл. 4 представлены основные характеристики полученных эконометрических моделей прогнозирования оплаты труда в разрезе агрегатов.

Все статистические характеристики удовлетворительны, а средние абсолютные ошибки (MAE), рассчитанные для каждой модели за период 2015-2017 гг. составили: «Промышленность» - 2,85\%; «Строительство» - 1,77\%; «Сельское, лесное и рыбное хозяйство» - 3,14\%; «Транспорт, информация и связь» - 2,80\%; «Торговля, ремонт автомобилей и мотоциклов, услуги по временному проживанию и питанию» - 2,29\%; «Прочие услуги» - 1,77\%.

Для отражения перехода от тарифной ставки первого разряда к базовой став- 
Прогнозирование основных параметров социально-экономического развития Республики Беларусь

Таблица 4

Значения критериев оценки качества регрессионных уравнений (17) - (22)

\begin{tabular}{|c|c|c|c|c|c|c|c|}
\hline № уравнения & $R^{2}$ & $R_{a}^{2}$ & $S E R$ & $D W$ & $J B$ & $B G$ & $W$ \\
\hline$(17)$ & 0,870 & 0,855 & 0,069 & 2,167 & $0,401(0,818)$ & $0,258(0,776)$ & $0,621(0,611)$ \\
\hline$(18)$ & 0,951 & 0,942 & 0,051 & 1,939 & $1,535(0,464)$ & $0,277(0,762)$ & $0,782(0,553)$ \\
\hline$(19)$ & 0,862 & 0,846 & 0,078 & 1,847 & $1,201(0,548)$ & $1,138(0,347)$ & $0,650(0,690)$ \\
\hline$(20)$ & 0,911 & 0,895 & 0,056 & 2,545 & $1,207(0,547)$ & $0,874(0,439)$ & $1,537(0,245)$ \\
\hline$(21)$ & 0,956 & 0,950 & 0,030 & 2,040 & $0,765(0,682)$ & $0,714(0,508)$ & $1,059(0,398)$ \\
\hline$(22)$ & 0,964 & 0,960 & 0,040 & 1,903 & $0,941(0,625)$ & $1,197(0,328)$ & $0,669(0,583)$ \\
\hline
\end{tabular}

Источник. Авторская разработка.

ке 26 возникает необходимость построения дополнительных уравнений оплаты труда, которые можно будет использовать в период оценивания коэффициента при базовой ставке. В связи с этим для всех агрегатов, за исключением «Транспорта, информации и связи», а также «Торговли, ремонта автомобилей и мотоциклов, услуг по временному проживанию и питанию», в которые показатель тарифной ставки первого разряда не входит, разработаны дополнительные уравнения (23) (26), которые могут служить временной заменой представленных выше уравнений при проведении прогнозов на 2020 г. ${ }^{27}$ :

«Промышленность» -

$\Delta \ln \left(c e_{1 t} /\right.$ ane $\left._{1 t}\right)=0,315 D U(1996-2008)_{t} \times \Delta \ln \left(W R_{t}\right)+$

$0,476 D U(1996-2008)_{t} \times \Delta \ln \left(l_{1 t}\right)+$

$+0,863 D U(2009)_{t} \times \Delta \ln \left(l_{1 t}\right)+0,262 \Delta \ln \left(X G_{t-2}\right)-$

$-0,173 D(2011)_{t}$;

«Строительство» -

$\Delta \ln \left(\right.$ ce $_{2 t} /$ ane $\left._{2 t}\right)=0,375 \Delta \ln \left(\right.$ Vocw $_{t} /$ ane $\left._{2 t}\right)+$ $+0,521 D U(2009)_{t} \times \Delta \ln \left(\operatorname{lp} p_{2 t}\right)+$

$+0,251 D U\left(1996 \_2008\right)_{t} \times \Delta \ln \left(W R_{t}\right)+$

$+0,334 D U\left(1996 \_2008\right)_{t} \times \Delta \ln \left(l p_{2 t}\right)$;

${ }^{26}$ В соответствии с Указом Президента Республики Беларусь от 18 января 2019 г. № 27 «Об оплате труда работников бюджетных организаций», с 1 января 2020 г. оплата труда осуществляется на основе тарифной системы, включающей в себя базовую ставку и 18-разрядную тарифную сетку. Размер базовой ставки будет определяться каждый год с 1 января с учетом прогноза основных социально-экономических параметров развития страны.

${ }^{27}$ В уравнениях (23) и (24) показатель тарифной ставки первого разряда домножен на фиктивную переменную изменения уровня, ограничивающую его влияние с 1996 до 2008 г. Это может быть объяснено тем, что вплоть до 2008 г. численность населения, занятого в государственных учреждениях, преобладала над численностью населения, занятого на частных предприятиях.
«Сельское, лесное и рыбное хозяйство» $\Delta \ln \left(\right.$ ce $_{3 t} /$ ane $\left._{3 t}\right)=0,245 \Delta \ln \left(X G_{t-1}\right)+$ $+0,705 \Delta \ln \left(g v a_{3 t}\right)+0,182 \Delta \ln \left(i n v_{t}\right)+$ $+0,342 D(2013)_{t}$;

«Прочие отрасли» -

$\Delta \ln \left(c e_{6 t} /\right.$ ane $\left._{6 t}\right)=1,038 \Delta \ln \left(l p_{6 t}\right)+0,045 \Delta \ln \left(i n v_{t-1}\right)-$

$-0,123 D(2010)_{t}$.

Дополнительно разработаны эконометрические модели для прогнозирования показателей «Объем подрядных работ» и «Розничный товарооборот»:

$\Delta \ln \left(\right.$ Vocw $\left._{t}\right)=0,425 \Delta \ln \left(i n v_{t-1}\right)-0,311 \Delta \ln \left(n r_{t}\right)-$

$-0,501 D(2015)_{t}$;

$\Delta \ln \left(R T_{t}\right)=0,884 \Delta \ln \left(M I N C_{t}\right)-0,056 \Delta \ln \left(n r_{t-1}\right)+$

$+0,110 D(2011)_{t}$.

Согласно методике по формированию счетов доходов ${ }^{28}$, к другим налогам на производство относятся: налог на недвижимость организаций (включая незавершенное строительство); земельный налог с организаций; налог за добычу (изъятие) природных ресурсов; экологический налог; государственные пошлины; патентные пошлины; сборы за осуществление деятельности; сбор за проезд автомобильных транспортных средств иностранных государств по автомобильным дорогам общего пользования Республики Беларусь. На основе статистической информации 2016-2018 гг., предоставляемой Министерством по налогам и сборам Республики Беларусь ${ }^{29}$, можно утверждать, что наибольший вклад в бюджет среди налогов, входящих в состав

${ }^{28}$ Методика по формированию счетов доходов, утвержденная постановлением Национального статистического комитета Республики Беларусь от 24 декабря 2015 г. № 210.

${ }^{29}$ URL: http://nalog.gov.by/ru/struktura-byudzheta-vrazreze-dohodnyh-istochnikov 
показателя «Другие налоги на производство», обеспечивают налог на недвижимость, земельный налог и налог за добычу (изъятие) природных ресурсов. Анализируя порядок установления налогов, описанный в Налоговом кодексе Республики Беларусь, можно сделать вывод, что все перечисленные налоги (кроме налога на недвижимость) можно отнести к налогам, не имеющим основной ставки. В квартальной модели QUMMIR (Савчишина, 2008), разработанной в ИНП РАН и используемой для прогнозирования показателей налогово-бюджетной сферы, поступления по налогам, не имеющих основной ставки, $\Delta \ln \left(\right.$ onpt $\left._{1 t}\right)=1,171 M A(1)-0,998 M A(2)-0,367 D(2009)_{t}-$ прогнозируются с использованием рег- $-0,325 D(2011)_{t}-0,402 D(2015)_{t}$; рессионных уравнений, в которых независимым параметром выступает переменная, соответствующая налогооблагаемой базе. Коэффициент при этой переменной является так называемой «эффективной ставкой» в том смысле, что отражает как изменение ста- $\Delta \ln \left(\right.$ onpt $\left._{4 t}\right)=-0,123 M A(1)-0,877 M A(3)-0,512 D(2009)_{t}-$ вок по налогу, так и уровня его соби- $-0,678 D(2011)_{t}-0,201 D U(2015)_{t}+0,163$; раемости. В открытом доступе не публикуется подробная статистика о на- $\Delta \ln \left(\right.$ onpt $\left._{5 t}\right)=0,252 A R(1)+0,954 M A(2)-0,857 D(2011)_{t}$ логооблагаемой базе для всех $-0,328 D(2015)$; рассматриваемых налогов; из-за этого подбор факторов, которые наиболее точно соответствовали бы определению налогооблагаемой базы, яв$\Delta \ln \left(\right.$ onpt $\left._{6 t}\right)=0,590 A R(1)-0,999 M A(3)+0,577 D(2008)_{t}-$ $-0,628 D(2011)_{t}+0,017$. ляется нетривиальной задачей. Для налога на недвижимость в качестве налогооблагаемой базы может выступать показатель «Основные средства организаций». В уравнении для налогов на добычу (изъятие) природных ресурсов в качестве экзогенных переменных может выступать валовой выпуск горнодобывающей промышленности. Однако данный показатель присутствует только в МОБ 2016-2017 гг. и отсутствует в более ранних версиях, поэтому его невозможно использовать при построении регрессионных уравнений. Для земельного налога выбрать показатели нелегко из-за сложной схемы его начисления (различные виды ставок в зависимости от функционального назначения и кадастровой стоимости земельного участка). Очевидно, что построение моделей прогнозирования налогов на производство в виде множественной линейной регрессии, в которой незави- где $A R(p)$ - авторегрессионная компонента порядка $p$, а $M A(q)$ - компонента скользящего среднего порядка $q$.

Основные статистические характеристики уравнений (29) - (34) приведены в табл. 5.

Средние относительные погрешности прогнозирования других налогов на производство за вычетом субсидий Республики Беларусь на 2015-2017 гг. в разрезе агрегатов с помощью уравнений (29) - (34) составили: «Промышленность» - 3,61\%; «Строительство» - 0,07\%; «Сельское, лесное и рыбное хозяйство» - 0,18\%; «Транспорт, информация и связь» - 5,07\%; «Торговля, ремонт автомобилей и мотоциклов,

30 Для В. р. других налогов на производство за вычетом субсидий в агрегатах «Строительство» и «Сельское, лесное и рыбное хозяйство» построение моделей в логарифмической форме невозможно, т. к. ряды содержат отрицательные значения (в 2015 г. в «Строительстве» и 1996, 2015-2017 гг. в «Сельском, лесном и рыбном хозяйстве»). 
Прогнозирование основных параметров социально-экономического развития Республики Беларусь

Таблица 5

Значения критериев оценки качества уравнений (29) - (34)

\begin{tabular}{|c|c|c|c|c|c|c|}
\hline $\begin{array}{c}\text { № } \\
\text { уравнения }\end{array}$ & $R^{2}$ & $R_{a}^{2}$ & $S E R$ & $J B$ & $B G$ & $B P G$ \\
\hline$(29)$ & 0,731 & 0,664 & 0,154 & $\begin{array}{c}1,240 \\
(0,538)\end{array}$ & $\begin{array}{c}0,580 \\
(0,573)\end{array}$ & $\begin{array}{c}2,110 \\
(0,137)\end{array}$ \\
\hline$(30)$ & 0,909 & 0,884 & 0,347 & $\begin{array}{c}0,841 \\
(0,657)\end{array}$ & $\begin{array}{c}1,014 \\
(0,390)\end{array}$ & $\begin{array}{c}1,411 \\
(0,276)\end{array}$ \\
\hline$(31)$ & 0,967 & 0,963 & 0,168 & $\begin{array}{c}0,944 \\
(0,621)\end{array}$ & $\begin{array}{c}0,416 \\
(0,667)\end{array}$ & $\begin{array}{c}0,142 \\
(0,934)\end{array}$ \\
\hline$(32)$ & 0,830 & 0,774 & 0,156 & $\begin{array}{c}0,018 \\
(0,991)\end{array}$ & $\begin{array}{c}1,577 \\
(0,244)\end{array}$ & $\begin{array}{c}0,421 \\
(0,740)\end{array}$ \\
\hline$(33)$ & 0,727 & 0,676 & 0,163 & $\begin{array}{c}0,327 \\
(0,849)\end{array}$ & $\begin{array}{c}0,074 \\
(0,929)\end{array}$ & $\begin{array}{c}0,257 \\
(0,776)\end{array}$ \\
\hline$(34)$ & 0,772 & 0,711 & 0,166 & $\begin{array}{c}0,612 \\
(0,736)\end{array}$ & $\begin{array}{c}2,674 \\
(0,107)\end{array}$ & $\begin{array}{c}0,614 \\
(0,553)\end{array}$ \\
\hline
\end{tabular}

Источник. Авторская разработка.

услуги по временному проживанию и питанию» - 3,07\%; «Прочие услуги» - 0,02\%.

\section{Прогнозные расчеты основных показателей социально-экономического развития Республики Беларусь на 2018 г.}

Для проведения прогнозных расчетов среди экзогенных параметров модели необходимо использовать те, которые будут учитывать экономическую политику, внешние условия, целевые ориентиры. Для прогнозирования ВВ в разрезе укрупненных агрегатов, а также элементов II и III квадрантов
МОБ в качестве экзогенных параметров взяты фактические значения переменных за 2018 г., представленные в табл. 6 .

С помощью неструктурных эконометрических моделей для элементов КПЗ получена прогнозная матрица. С использованием данной матрицы КПЗ, прогнозных значений ВВ и ЧНП, а также моделей для прогнозирования основных элементов конечного использования по республике и элементов третьего квадранта МОБ, рассчитаны прогнозные значения основных макропоказателей социально-экономического развития Республики Беларусь на 2018 г. (табл. 7).

В целом, относительные погрешности прогнозирования в разрезе агрегатов оказались удовлетворительными и не превысили: 5,99\% - для ВВ; 2,50\% - для ВДС; 3,67\% для оплаты труда работников; 5,53\% - для других налогов на производство за вычетом субсидий и 4,07\% - для валовой прибыли и валового смешанного дохода. Относительную погрешность прогнозирования конечной продукции на уровне республики невозможно оценить ввиду отсутствия на данный момент статистической информации.

Предложенная версия балансово-эконометрической межотраслевой модели обо-

Таблица 6

Фактические значения экзогенных параметров за 2018 г., используемые для прогнозирования основных показателей социально-экономического развития Республики Беларусь

\begin{tabular}{|c|c|}
\hline Показатель, единица измерения & Значение показателя \\
\hline ВВП России, млн долЛ. США & 1657554,7 \\
\hline Цена импорта сырой нефти, долл. США/т & 374,1 \\
\hline Цена импорта природного газа, долл. США/ $1000 \mathrm{~m}^{3}$ & 133 \\
\hline $\begin{array}{l}\text { Номинальный курс белорусского рубля по отношению к доллару США, } \\
\text { руб/долл. США }\end{array}$ & 2,0366 \\
\hline Реальный курс белорусского рубля к российскому рублю, руб/рос. руб. & 3,2364 \\
\hline Потребление электроэнергии, млрд кВт·ч & 37,9 \\
\hline Доходы от услуг связи, млн руб. & 3369,1 \\
\hline Номинальная начисленная среднемесячная заработная плата, руб. & 971,4 \\
\hline $\begin{array}{l}\text { Номинальная ставка рефинансирования Национального банка Республики } \\
\text { Беларусь, \% }\end{array}$ & 10,3 \\
\hline \multicolumn{2}{|l|}{ Численность занятых в разрезе агрегатов, тыс. чел. } \\
\hline промышленность & 1018,1 \\
\hline строительство & 274,5 \\
\hline сельское, лесное и рыбное хозяйство & 405,4 \\
\hline транспорт, информация и связь & 408,2 \\
\hline $\begin{array}{l}\text { торговля, ремонт автомобилей и мотоциклов, услуги по временному } \\
\text { проживанию и питанию }\end{array}$ & 720,0 \\
\hline прочие услуги & 1509,3 \\
\hline Основные средства в агрегате «Сельское, лесное и рыбное х & 33126,6 \\
\hline
\end{tabular}

Источник. Данные Национального статистического комитета Республики Беларусь, Национального банка Республики Беларусь, Всемирного банка. 
Прогнозные значения основных показателей социально-экономического развития

Республики Беларусь на 2018 г., млн руб.

\begin{tabular}{|c|c|c|c|c|c|c|c|c|}
\hline \multirow{2}{*}{ Показатель } & \multicolumn{6}{|c|}{ № агрегата } & \multirow{2}{*}{$\begin{array}{c}\text { На уровне } \\
\text { республики }\end{array}$} & \multirow{2}{*}{$\begin{array}{c}\text { Ошибка } \\
\text { прогноза, \% }\end{array}$} \\
\hline & 1 & 2 & 3 & 4 & 5 & 6 & & \\
\hline ВВП & - & - & - & - & - & - & 122679,48 & 0,91 \\
\hline $\begin{array}{l}\text { Конечное } \\
\text { потребление }\end{array}$ & - & - & - & - & - & - & 85067,81 & 1,58 \\
\hline $\begin{array}{l}\text { Валовое } \\
\text { накопление }\end{array}$ & - & - & - & - & - & - & 35871,24 & 4,44 \\
\hline Валовой выпуск & 111310,12 & 16384,11 & 22018,14 & 21250,39 & 25622,38 & 45154,62 & - & - \\
\hline ЧНП & 3460,41 & 300,30 & $-520,68$ & 427,71 & 377,18 & 862,05 & 17524,90 & 0,05 \\
\hline ВДС & 32003,07 & 6664,70 & 8158,38 & 13851,34 & 13089,92 & 31387,17 & 105154,58 & 0,35 \\
\hline $\begin{array}{l}\text { Оплата труда } \\
\text { работников }\end{array}$ & 15056,01 & 3698,00 & 3725,63 & 8788,38 & 7936,05 & 19036,00 & 58240,07 & 0,13 \\
\hline $\begin{array}{l}\text { Другие налоги на } \\
\text { производство за } \\
\text { вычетом субсидий }\end{array}$ & 1466,49 & 46,77 & $-157,14$ & 345,23 & 225,57 & 149,85 & 2076,77 & 5,26 \\
\hline $\begin{array}{l}\text { Валовая прибыль } \\
\text { и валовой } \\
\text { смешанный доход }\end{array}$ & 15480,57 & 2919,93 & 4589,89 & 4717,73 & 4928,30 & 12201,32 & 44837,74 & 0,43 \\
\hline $\begin{array}{l}\text { Конечная } \\
\text { продукция }\end{array}$ & 27766,14 & 15758,91 & 2851,91 & 15067,31 & 15959,83 & 32657,45 & 110061,55 & - \\
\hline Экспорт & - & - & - & - & - & - & 84861,80 & 1,68 \\
\hline Импорт & - & - & - & - & - & - & 83121,37 & 1,24 \\
\hline $\begin{array}{l}\text { Чистый экспорт } \\
\text { (сальдо) }\end{array}$ & - & - & - & - & - & - & 1740,43 & 6,17 \\
\hline
\end{tabular}

Примечание. Прочерки в таблице означают, что расчеты по данным показателям в разрезе укрупненных агрегатов не проводились.

Источник. Авторская разработка.

снована с позиций экономической теории и эконометрики, дает приемлемую точность прогноза и может быть использована для прогнозирования как основных параметров социально-экономического развития, так и отраслевой структуры экономики Республики Беларусь.

\section{СПИСОК ЛИТЕРАТУРЫ (REFERENCES)}

Айвазян С.А., Березняцкий А.Н., Бродский Б.Е. 2019. Неравновесные структурные модели реального сектора российской экономики. Экономика и математические методъ. Т. 55. № 2. C. 65-80. [Brodsky B.E., Aivazian S.A., Bereznyatskiy A.N. 2019. Non-equilibrium structural models of the real sector of the Russian economy. Ekonomika $i$ matematicheskie metody. Vol. 55. No 2. PP. 6580. (In Russ.)]

Аксень Э.М. 2019. Стохастическая динамическая балансовая модель для выпусков отраслей с использованием коэффициентов пропорций инвестирования. Экономика, моделирование, прогнозирование: сборник научных трудов. Минск: НИЭИ Министерства экономики Республики Беларусь. Вып. 13. С. 125-132. [Aksen E.M. 2019. Stochastic dynamic balance model for industry outputs using investment ratios. Ekonomika, modelirovanie, prognozirovanie. Minsk: NIEI
Ministerstva ekonomiki Respubliki Belarus'. Iss. 13. PP. 125-132. (In Russ.)]

Алмон К. 2016. Межотраслевые модели INFORUM: происхождение, развитие и преодоление проблем. Проблемы прогнозирования. № 2. С. 315. [Almon K. 2016. Intersectoral INFORUM models: The origin, development and overcoming of problems. Problemy prognozirovaniya. No 2. PP. 3-15. (In Russ.)]

Алмон К. 2018. В чем важность таблиц «Затраты - Выпуск». Проблемы прогнозирования. № 6 . C. 7-11. [Almon K. 2018. Government Social Expenditures in the Draft Federal Budget of Russia for 2018-2020. Problemy prognozirovaniya. No 6. PP. 7-11. (In Russ.)]

Баранов A.О., Павлов В.Н., Слепенкова Ю.М., Тагаева Т.О. 2018. Использование динамической межотраслевой модели с блоком человеческого капитала в прогнозировании экономики России. Проблемы прогнозирования. № 6. С. 104110. [Baranov A.O., Pavlov V.N., Slepenkova I.M., Tagaeva T.O. 2018. Dynamic input-output model with a human capital block applied to forecasting of the Russian economy. Problemy prognozirovaniya. No 6. PP. 104-110. (In Russ.)]

Баранов Э.Ф., Пионтковский Д.И., Старицына Е.А. 2019. Методологические проблемы использования метода структурной декомпозиции в модели «Затраты - Выпуск» на современном этапе. Проблемы прогнозирования. № 2. С. 2736. [Baranov E.F., Piontkovski D.I., Staritsyna E.A. 2019. Methodological problems of using the structural 
decomposition analysis in the input-output model at the present stage. Problemy prognozirovaniya. No 2 . PP. 27-36. (In Russ.)]

Бардацци Р., Гецци Л. 2018. Многоуровневая система макроструктурных моделей. Проблемь прогнозирования. № 6. C. 26-37. [Bardazzi R., Ghezzi L. 2018. A multi-scale system of macroeconometric models: The Inforum approach. Problemy prognozirovaniya. No 6. PP. 26-37. (In Russ.)]

Борейко Н.Н., Селицкая А.Ю., Никонович А.А. 2018. Прогнозирование ВВП Республики Беларусь производственным методом на основе системы эконометрических моделей. Экономика, моделирование, прогнозирование: сборник научных трудов. Минск: НИЭИ Министерства экономики Республики Беларусь. Вып. 12. С. 248-259. [Boreyko N.N., Selitskaya A.Yu., Nikonovich A.A. 2018. GDP forecasting of the Republic of Belarus by the production method based on a system of econometric models. Ekonomika, modelirovanie, prognozirovanie. Minsk: NIEI Ministerstva ekonomiki Respubliki Belarus'. Iss. 12. PP. 248-259. (In Russ.)]

Быков А.А., Роднянский Д.В., Хаустович Н.А., Шутилин В.Ю. 2019. Экономический анализ «воплощенной энергии»: методология и возможности применения. Белорусский экономический журнал. № 4. С. 71-85. [Bykau A., Rodnyansky D., Khaustovich N., Shutsilin V. 2019. «Embodied energy» economic analysis: Methodology and applications. Belorusskjy ekonomicheskiy zhurnal. No 4. PP. 71-85. (In Russ.)]

Господарик Е.Г., Ковалев М.М. 2015. ЕАЭС2050: глобальные тренды и евразийская экономическая политика. Минск: БГУ. 152 с. [Gospodarik E.G., Kovalev M.M. 2015. EAEU-2050: Global trends and Eurasian economic policy. Minsk: BGU. 152 p. (In Russ.)]

Гранберг А.Г. 1985. Динамические модели народного хозяйства. Москва: Экономика. 240 с. [Granberg A.G. 1985. Dynamic models of the national economy. Moscow: Ekonomika. 240 p. (In Russ.)]

Ивантер В.В. 2018. Роль межотраслевого баланса в макроэкономическом анализе и прогнозировании. Проблемы прогнозирования. № 6. C. 3-6. [Ivanter V.V. 2018. Role of input-output model in macroeconomic analysis and forecasting. Problemy prognozirovaniya. No 6. PP. 3-6. (In Russ.)]

Картун А.М. 2019. Комплексная методика прогнозной оценки уровня инфляции в Республике Беларусь. Экономика, моделирование, прогнозирование: сборник научных трудов. Минск: НИЭИ Министерства экономики Республики Беларусь. Вып. 13. С. 202-209. [Kartun A.M. 2019. A comprehensive methodology for forecasting inflation in the Republic of Belarus. Ekonomika, modelirovanie, prognozirovanie. Minsk: NIEI
Ministerstva ekonomiki Respubliki Belarus'. Iss. 13. PP. 202-209. (In Russ.)]

Кравцов М.К. 2016. Прогнозирование макроэкономических показателей на основе двухэтапной балансово-оптимизационной межотраслевой модели. Экономика, моделирование, прогнозирование: сборник научных трудов. Минск: НИЭИ Министерства экономики Республики Беларусь. Вып. 10. С. 196-207. [Kravtsov M.K. 2016. Forecasting macroeconomic indicators based on the two-stage inter-sectoral balance optimization model. Ekonomika, modelirovanie, prognozirovanie. Minsk: NIEI Ministerstva ekonomiki Respubliki Belarus'. Iss. 10. PP. 196-207. (In Russ.)]

Кравцов М.К. 2017. Методический подход к построению комплексной динамической межотраслевой модели среднесрочного прогнозирования основных макропоказателей белорусской экономики. Экономика, моделирование, прогнозирование: сборник научных трудов. Минск: НИЭИ Министерства экономики Республики Беларусь. Вып. 11. С. 202-213. [Kravtsov M.K. 2017. Methodical approach to the development of an integrated, dynamic intersectoral model for the medium-term forecasting of the main macroeconomic indicators of Belarusian economy. Ekonomika, modelirovanie, prognozirovanie. Minsk: NIEI Ministerstva ekonomiki Respubliki Belarus'. Iss. 11. PP. 202-213. (In Russ.)]

Кравцов М.К., Антаневич А.А. 2015а. Прогнозирование важнейших показателей белорусской экономики на основе балансово-оптимизационной модели. Белорусский экономический журнал. № 1. C. 110-123. [Kravtsov M., Antanevich A. 2015a. Forecasting main indicators of Belarus's economy based on balance-optimization model. Belorusskjy ekonomicheskiy zhurnal. No 1. PP. 110-123. (In Russ.)]

Кравцов М.К., Антаневич А.А. 2015b. Прогнозирование макроэкономических показателей на основе балансово-оптимизационной модели. Экономический бюллетень НИЭИ Министерства экономики Республики Беларусь. № 7. С. 4-13. [Kravtsov M., Antanevich A. 2015b. National measure forecasting based on balance and optimization model. Ekonomicheskiy byulleten' NIEI Ministerstva ekonomiki Respubliki Belarus'. No 7. PP. 4-13. (In Russ.)]

Кравцов М.К., Антаневич А.А., Безрукова Н.Ю. 2014. Вычислительные эксперименты по исследованию математических моделей прогнозирования коэффициентов прямых затрат. Экономика, моделирование, прогнозирование: сборник научных трудов. Минск: НИЭИ Министерства экономики Республики Беларусь. Вып. 8. С. 188-205. [Kravtsov M.K., Antanevich A.A., Bezrukova N.Yu. 2014. Computational experiments on the study of mathematical models for predicting direct cost coefficients. Ekonomika, modelirovanie, prognozirovanie. 
Minsk: NIEI Ministerstva ekonomiki Respubliki Belarus'. Iss. 8. PP. 188-205. (In Russ.)]

Кравцов М.К., Борейко Н.Н., Никитина А.К. 2013. Сценарное прогнозирование важнейших показателей белорусской экономики на основе расширенной версии эконометрической макромодели. Экономика, моделирование, прогнозирование: сборник научных трудов. Минск: НИЭИ Министерства экономики Республики Беларусь. Вып. 7. С. 220-235. [Kravtsov M.K., Boreyko N.N., Nikitina A.K. 2013. Scenario forecasting of the most important indicators of the Belarusian economy based on an expanded version of the econometric macro model. Ekonomika, modelirovanie, prognozirovanie. Iss. 7. Minsk: NIEI Ministerstva ekonomiki Respubliki Belarus'. PP. 220235. (In Russ.)]

Кравцов М.К., Борейко Н.Н., Никитина А.К. 2014. Информационные и методические аспекты построения балансово-эконометрической межотраслевой модели отечественной экономики. Экономи$\kappa a$, моделирование, прогнозирование: сборник научных трудов. Минск: НИЭИ Министерства экономики Республики Беларусь. Вып. 8. С. 39-49. [Kravtsov M.K., Boreyko N.N., Nikitina A.K. 2014. Information and methodical aspects of construction of input-output econometric interindustry. Ekonomika, modelirovanie, prognozirovanie. Minsk: NIEI Ministerstva ekonomiki Respubliki Belarus'. Iss. 8. PP. 39-49. (In Russ.)]

Кравцов М.К., Бурдыко Н.М., Гаспадарец О.И., Шинкевич Н.Н., Картун А.М. 2008. Эконометрическая макромодель для анализа и прогнозирования важнейших показателей белорусской экономики. Прикладная эконометрика. № 2. С. 21-43. [Kravtsov M.K., Burdyko N.M., Gaspadarets O.I., Shinkevich N.N., Kartun A.M. 2008. Econometric macromodel for analysis and forecasting of the most important indicators of the Belarusian economy. Prikladnaya ekonometrika. No 2. PP. 21-43. (In Russ.)]

Кравцов М.К., Гладкая А.А. 2019. Использование неструктурных эконометрических моделей и расширенной версии метода Хорафаса для прогнозирования коэффициентов прямых затрат. Проблемы прогнозирования и государственного регулирования социально-экономического развития: материалы XX Международной научной конференции. Минск: НИЭИ Министерства экономики Республики Беларусь. Т. 1. С. 163-176. [Kravtsov M.K., Gladkaya A.A. 2019. Non-structural econometric models and an extended version of the Horafas method for predicting input-output coefficients. Problemy prognozirovanija $i$ gosudarstvennogo regulirovanija social'no-jekonomi-cheskogo razoitija. Minsk: NIEI Ministerstva ekonomiki Respubliki Belarus'. Vol. 1. PP. 163-176. (In Russ.)]

Кравцов М.К., Крукова А.А. 2005. Многокритериальный подход к моделированию взаи- модействия экономики, энергетики и охраны окружающей среды. Экономика и управление. № 4. C. 13-18. [Kravtsov M.K., Krukova A.A. 2005. A multi-criteria approach to modeling the interaction of economics, energy and environmental protection. Ekonomika i upravlenie. No 4. PP. 13-18. (In Russ.)]

Кравцов М.К., Лазовский В.Г. 2018. Прогнозирование коэффициентов прямых затрат на основе расширенной версии метода Хорафаса. Экономический бюллетень НИЭИ Министерства экономики Республики Беларусь. № 11. С. 4-12. [Kravtsov M.K., Lazovsky V.G. 2018. Input-output coefficients forecasting based on balance and optimization model. Ekonomicheskiy byulleten' NIEI Ministerstva ekonomiki Respubliki Belarus'. No 11. PP. 4-12. (In Russ.)]

Кравцов М.К., Лазовский В.Г., Федченко Л.В. 2018. Прогнозирование макропоказателей белорусской экономики на основе динамической балансово-эконометрической межотраслевой модели. Экономика, моделирование, прогнозирование: сборник научных трудов. Минск: НИЭИ Министерства экономики Республики Беларусь. Вып. 12. C. 202-219. [Kravtsov M.K., Lazovski V.G., Fedchenko L.V. 2018. Forecasting of the macroeconomic indicators of the Belarusian economy on the basis of the dynamic balance-econometric interindustry model. Ekonomika, modelirovanie, prognozirovanie. Minsk: NIEI Ministerstva ekonomiki Respubliki Belarus'. Iss. 12. PP. 202-219. (In Russ.)]

Кравцов М.К., Пашкевич А.В. 2004. Многокритериальный подход к оптимизации валового внутреннего продукта. Автоматика и телемеханика. № 2. С. 198-207. [Kravtsov M.K., Pashkevich A.V. 2004. A multi-criteria approach to optimizing gross domestic product. Avtomatika $i$ telemekhanika. No 2. PP. 198-207. (In Russ.)]

Кравцов М.К., Пашкевич А.В., Бурдыко Н.М. 2005. Эконометрический анализ временных рядов основных макроэкономических показателей. Белорусская экономика: анализ, прогноз, регулирование. № 3. C. 3-22. [Kravtsov M.K., Pashkevich A.V., Burdyko N.M. 2005. Econometric time series analysis of key macroeconomic indicators. Belorusskaya ekonomika: analiz, prognoz, regulirovanie. No 3. PP. 322. (In Russ.)]

Кравцов М.К., Пашкевич А.В., Подкопаев Д.П. 2002. Двухкритериальная модель оптимизации валового внутреннего продукта с учетом рационального использования топливно-энергетических ресурсов. Белорусская экономика: анализ, прогноз, регулирование. № 12. С. 23-29. [Kravtsov M.K., Pashkevich A.V., Podkopaev D.P. 2002. Two-criteria model for optimizing gross domestic product, taking into account the rational use of fuel and energy resources. Belorusskaya ekonomika: analiz, prognoz, regulirovanie. No 12. PP. 23-29. (In Russ.)] 
Макаров В.Л., Бахтизин А.Р., Бекларян Г.Л., Акопов А.С., Ровенская Е.А. Стрелковский Н.В. 2019. Укрупненная агент-ориентированная имитационная модель миграционных потоков стран Европейского союза. Экономика и математические методы. T. 55. № 1. C. 3-15. [Makarov V.L., Bakhtizin A.R., Beklaryan G.L., Akopov A.S., Rovenskaya E.A, Strelkovskii N.V. 2019. Aggregated agentbased simulation model of migration flows of the European Union countries. Ekonomika i matematicheskie metody. Vol. 55. No 1. PP. 3-15. (In Russ.)]

Малюгин В.И. 2014. Методы анализа многомерных эконометрических моделей с неоднородной структурой. Минск: БГУ. 351 с. [Malugin V. 2014. Methods of analysis of multidimensional econometric models with a heterogeneous structure. Minsk: BGU. 351 p. (In Russ.)]

Масакова И.Д. 2019. Российская практика составления таблиц «Затраты - Выпуск»: проблемы и перспективы развития. Проблемы прогнозирования. № 2. C. 14-26. [Masakova I.D. 2019. The Russian practice of compiling input-output tables: Problems and prospects of development. No 2. PP. 14-26. (In Russ.)]

Никитина А.К. 2018. Прогнозирование коэффициентов прямых затрат на основе неструктурных эконометрических моделей. Экономика, моделирование, прогнозирование: сборник научных трудов. Минск: НИЭИ Министерства экономики Республики Беларусь. Вып. 12. С. 267-278. [Nikitsina A.K. 2018. Forecasting the input-output coefficients based on the non-structural econometric models. Ekonomika, modelirovanie, prognozirovanie. Minsk: NIEI Ministerstva ekonomiki Respubliki Belarus'. Iss. 12. PP. 267-278. (In Russ.)]

Савчишина К.Е. 2008. Прогнозирование показателей налогово-бюджетной сферы в рамках квартальной макроэкономической модели QUMMIR. Научные труды: Институт народнохозяйственного прогнозирования РАН. Т. 6. С. 225241. [Savchishina K.E. 2008. The Forecasting of Budget and Tax Parameters in the Framework of the QUMMIR Macroeconomic Model. Nauchnye trudy: Institut narodnokhozyaystvennogo prognozirovaniya RAN. Vol. 6. PP. 225-241. (In Russ.)]

Саяпова А.Р., Сыртланов И.В., Широв А.А. 2015. Межстрановой анализ пространственно-временных характеристик технологических коэффициентов. Проблемы прогнозирования. № 6. С. 31-44. [Sayapova A.R., Syrtlanov I.V., Shirov A.A. 2015. Cross-country analysis of spatiotemporal characteristics of technological coefficients. Problemy prognozirovaniya. No 6. PP. 31-44. (In Russ.)]

Суслов В.И., Доможиров Д.А., Ибрагимов Н.М., Костин В.С., Мельникова Л.В., Цыплаков А.А. 2016. Агент-ориентированная многорегиональная модель «Затраты - Выпуск» рос- сийской экономики. Экономика и математические методы. Т. 52. № 1. С. 112-131. [Suslov V.I., Domozhirov D.A., Ibragimov N.M., Kostin V.S., Melnikova L.V., Tsyplakov A.A. 2016. Agent-based multiregional input-output model of the Russian economy. Ekonomika $i$ matematicheskie metody. Vol. 52. No 1. PP. 112-131. (In Russ.)]

Харемза В.В., Харин Ю.С., Макарова С.Б., Малюгин В.И., Майковская В.Н., Гурин А.С., Вымятнина Ю.В., Раскина Ю.В. 2007. Моделирование и прогнозирование макроэкономических показателей экономик Беларуси, России и Украины на основе межстрановой модели LAM ICM. Экономический бюллетень НИЭИ Министерства экономики Республики Беларусь. № 4. С. 18-34. [Kharemza V.V., Kharin Y.S., Makarova S.B., Malyughin V.I., Maykovskaya V.N., Gurin A.S., Vymyatnina Y.V., Raskina Y.V. 2007. Simulation and forecasting of macroeconomic indices of Belarus, Russia and Ukraine economies on basis of inter-country's model LAM ICM. Ekonomicheskiy byulleten' NIEI Ministerstva ekonomiki Respubliki Belarus'. No 4. PP. 18-34. (In Russ.)]

Шимов В.Н., Александрович Я.М., Богданович А.В., Ткачев С.П. 2001. Прогнозирование социально-экономического развития Республики Беларусь: вотросы теории и методики. Минск: НИЭИ Министерства экономики Республики Беларусь. 336 с. [Shimov V.N., Aleksandrovich Ja.M., Bogdanovich A.V., Tkachev S.P. 2001. Prediction of the socio-economic development of the Republic of Belarus: theory and methodology. Minsk: NIEI Ministerstva ekonomiki Respubliki Belarus'. 336 p. (In Russ.)]]

Широв А.А. 2018. Использование таблиц «Затраты - Выпуск» для обоснования решений в области экономической политики. Проблемы прогнозирования. № 6. C. 12-25. [Shirov A.A. 2018. Use of input-output approach for supporting decisions in the field of economic policy. Problemy prognozirovaniya. No 6. PP. 12-25. (In Russ.)]

Широв А.А., Янтовский А.А. 2017. Межотраслевая макроэкономическая модель RIM - развитие инструментария в современных экономических условиях. Проблемы прогнозирования. № 3. С. 218. [Shirov A.A., Yantovskii A.A. 2017. RIM interindustry macroeconomic model: Development of instruments under current economic conditions. Problemy prognozirovaniya. No 3. PP. 2-18. (In Russ.)]

Chonghui G., Huanwen T. 2002. Stability analysis of the dynamic input-output system. Applied Mathematics - A Journal of Chinese Universities. Series B. Vol. 17. No 4. PP. 473-478.

Corong E.L., Hertel T.W., McDougall R., Tsigas M.E., van der Mensbrugghe D. 2017. The standard GTAP model, version 7. Journal of Global Economic Analysis. Vol. 2. No 1. PP. 1-119. URL: http://dx.doi.org/10.21642/JGEA.020101AF

Dietzenbacher E., Los B., Stehrer R., Timmer M., de Vries G. 2013. The construction of the world 
input output tables in the WIOD project. Economic Systems Research. Vol. 25. No 1. PP. 71-98.

Kurz H.D., Salvadori N. 2000. The dynamic Leontief model and the theory of endogenous growth. Economic Systems Research. Vol. 12. No 2. PP. 255265.

Lenzen M., Moran D., Kanemoto K., Geschke A. 2013. Building EORA: A global multi-region input-output database at high country and sector resolution. Economic Systems Research. Vol. 25. No 1. PP. 20-49.

Miller R.E., Blair P.D. 2009. Input-output analysis: foundations and extensions. Cambridge: Cambridge University Press. 750 p.

Wang Q. 2000. Trade flows and trade protection: A multi-country and multi-sectoral investigation. University of Maryland. URL: http://ma.umd.edu/ papers/publishedwork/dissertations/wang.pdf

\title{
PREDICTING THE KEY PARAMETERS OF SOCIO-ECONOMIC DEVELOPMENT OF THE REPUBLIC OF BELARUS BASED ON A DYNAMIC INPUT-OUTPUT MODEL
}

\author{
Mihail Kravtsov ${ }^{1}$, Aleksandra Gladkaya ${ }^{1}$, Tat'iana Dehtyar ${ }^{1}$ \\ Authors affiliation: ${ }^{1}$ Economy Research Institute of the Ministry of Economy of the Republic of Belarus \\ (Minsk, Belarus).
}

Corresponding author: Aleksandra Gladkaya (gladkayaalexandra@gmail.com).

ABSTRACT. The article provides the extended version of input-output balance and econometric model for predicting key macro-indicators of the Belarusian economy, which has been developed by the Economy Research Institute (the ERI) of the Ministry of Economy of the Republic of Belarus. Special attention has been given to such indicators as compensation of employees, gross operating surplus and gross mixed income, and other net taxes on production. All econometric models for predicting input-output coefficients, gross output by aggregates and the key elements of final use at the republican level have been overestimated and some models have been improved. Based on statistical information of the Republic of Belarus 2017-2018 predictive calculations have been performed, which have the acceptable forecast accuracy and indicate the possibility of using the proposed models in the development of forecasts and programs for the country's socio-economic development.

KEYWORDS: input-output model, input-output tables, dynamic interindustry model, econometric models. JEL-code: D57, O11, E17.

DOI: $10.46782 / 1818-4510-2020-2-4-24$

Received 3.03.2020 